\title{
Robert Peters*
}

robert.peters@eui.eu

Berlin, Germany

\section{The Protection of Cultural Property: Recent Developments in Germany in the Context of New EU Law and the 1970 UNESCO Convention}

\begin{abstract}
This article analyses the new German cultural property law in the context of EU law and the 1970 UNESCO Convention on the protection of cultural property. The analysis starts by looking at the circumstances that led to the 2016 reform of Germany's cultural property law. It then widens the perspective by looking at the overall legal framework of the Single European Market (SEM) in the context of the free movement of goods and the protection of cultural property. Both, the new Directive 2014/60/EU on the return of cultural property as well as the EU Regulation 116/2009 on the export of cultural property are scrutinized with a specific focus on their impact in shaping and developing national cultural property law. Specific focus is placed on the divergent notions of "national treasures" and "national patrimony" in Article 36 of the EU Treaty. On the basis of this overall legal framework, the four pillars of the 2016 German cultural property reform are described. The article concludes by showing what is lacking in current EU law: an import regulation for cultural property. Without such an import regulation,
\end{abstract}

\footnotetext{
* Robert Peters works as Legal Officer for the Federal Government Commissioner for Culture and the Media, Germany, in the division "National and International Protection of Movable Cultural Property" since 2009. He studied International and European Law in Berlin, Bologna, Hamburg and Florence and obtained his Ph.D. in the field of International Cultural Heritage Law with a specific focus on restitution disputes at the European University Institute in Florence, Italy. Prior, he worked as Assistant Legal Officer in the Office of International Standards and Legal Affairs at UNESCO Headquarters in Paris. This article expresses personal views of the author.
} 
the 1970 UNESCO Convention cannot have full effect in the SEM and its EU Member States.

Keywords: Germany, EU, Single European Market, 1970 UNESCO Convention, import and export, return of cultural property, due diligence

\section{Introduction}

With the adoption of the new cultural property law by the German parliament in June 2016, Germany instituted a new legal framework for the protection of cultural property. ${ }^{1}$ The new law, which entered into force on $6^{\text {th }}$ August 2016, includes measures on the protection of Germany's own national cultural heritage as well as measures on the protection of other nations' cultural heritage via the introduction of import restrictions on cultural property protected by other states' national laws. Germany's new law consists of four major aspects, which can be seen as the four pillars of the 2016 reform: (1) import and export provisions; (2) provisions for the return of cultural property; (3) due diligence provisions in dealing with cultural property; and (4) penal sanctions.

Although a legal framework for the protection of Germany's national cultural property has existed since 1919 , and was replaced by a law in $1955,{ }^{2}$ it was the creation of the Single European Market (SEM) in the European Union (EU) in 1993 and the ratification of the 1970 UNESCO Convention ${ }^{3}$ by Germany in 2007 that added two fundamental new aspects to German cultural property law: the obligation to return illegally exported cultural property to EU Member States as well as to States Parties to the 1970 UNESCO Convention; and the obligation to control the export of cultural property in case of an export outside the SEM via the issuance of an EU export license. Both aspects required new legislation in 2007 and, more im-

1 Gesetz zur Neuregelung des Kulturgutschutzrechts - KGSG [Act of 31 July 2016 Reforming the Law on the Protection of Cultural Property], Bundesgesetzblatt (BGBI.) 2016 I S. 1914, entered into force on 6 August 2016; hereinafter: Act of 31 July 2016, http://www.gesetze-im-internet.de/kgsg/index.html [accessed: 21.09.2016].

2 Gesetz zum Schutz Deutschen Kulturgutes gegen Abwanderung - KultgSchG [Act to Prevent the Exodus of German Cultural Property], in the version published on 8 July 1999 (Federal Law Gazette, Part I, p. 1754), as most recently amended by Article 2 of the Gesetz zur Ausführung des UNESCO-Übereinkommens vom 14. November 1970 über Maßnahmen zum Verbot und zur Verhütung der rechtswidrigen Einfuhr, Ausfuhr und Übereignung von Kulturgut [Act of 18 May 2007 Implementing the UNESCO Convention of 14 November 1970 on the Means of Prohibiting and Preventing the Illicit Import, Export and Transfer of Ownership of Cultural Property] (Federal Law Gazette, Part I, p. 757). 
portantly, led to the fundamental reform of German cultural property law in 2016 through the introduction of a new cultural property protection law. ${ }^{4}$ Although publicly criticized by the German art and antiquities market as being onerous and too restrictive, ${ }^{5}$ the 2016 law sets new standards in protecting cultural property and fighting illicit trafficking in cultural property.

\section{German legislation in the context of EU Law and the 1970 UNESCO Convention}

Whereas the EU Regulation 116/2009 on the export of cultural property ${ }^{6}$ is binding in its entirety and directly applicable in all EU Member States, both the Directive 2014/60/EU7 and the 1970 UNESCO Convention needed to be transposed into national law. Germany transposed the Council Directive 93/7/EEC, ${ }^{8}$ the predecessor of the new 2014 EU Directive, in 1998. The 1970 UNESCO Convention, in turn, was transposed by amending the 1998 law in 2007, the same year Germany ratified the 1970 UNESCO Convention. However, the 2007 law was a political compromise and did not harmonize with legal provisions dating back to 1955 . The lack of reform of the 1955 law protecting Germany's national cultural property stands in contrast to the development of German laws protecting foreign cultural property based on the EU Directive and the 1970 UNESCO Convention. This divergence can only be surprising because the protection of national cultural property on the one hand, and the protection of foreign cultural property on the other, are two sides of the same coin. Therefore, the German federal government launched a report in $2013^{9}$ - while waiting for the recast of the Council Directive 93/7/EEC - evaluating the existing German cultural property laws. The comprehensive federal government report, focusing specifically on the laws of 1955 and 2007, came to the conclusion that rather than just single amendments, an entire revision of the existing laws was needed. The report presented to Parliament (Bundestag) and the Federal Council

\footnotetext{
4 Act of 31 July 2016, op. cit.

5 See for example: A. Forbes, I. Kaplan, Germany's onerous new art export law, explained, "Artsy Editorial", 12 July 2016, https://www.artsy.net/article/artsy-editorial-what-germany-s-strict-new-regulations-mean-for-the-international-art-market [accessed: 21.09.2016].

6 Council Regulation (EC) No. 116/2009 of 18 December 2008 on the export of cultural goods (codified version), OJ L 39, 10.02.2009, p. 1.

7 Directive 2014/60/EU of the European Parliament and of the Council of 15 May 2014 on the return of cultural objects unlawfully removed from the territory of a Member State and amending Regulation (EU) No. 1024/2012, OJ L 159, 28.05.2014, p. 1.

8 Council Directive 93/7/EEC of 15 March 1993 on the return of cultural objects unlawfully removed from the territory of a Member State, OJ L 74, 27.03.1993, p. 74.

9 Report of the Federal Government on the protection of cultural property in Germany, adopted and presented to parliament (Bundestag) and the federal council of the Länder (Bundesrat) in April 2013 (Drucksache des Bundestages 17/13378), https://www.bundesregierung.de/ContentArchiv/DE/Archiv17/Artikel/2013/04/2013-04-24-kulturgutschutz.html [accessed: 21.09.2016].
} 
of the Länder (Bundesrat) recommended not only the improvement of legislation in order to counter several shortcomings, inconsistencies and loopholes in the existing laws, but also to unify the different laws into one uniform act. Consequently, in November 2015 the German government presented a uniform draft law on the protection of cultural property..$^{10}$ This law (1) transposes the new Directive 2014/60/EU; (2) improves the implementation of the 1970 UNESCO Convention; (3) includes provisions on the 1954 Hague Convention: ${ }^{11}$ and (4) streamlines the 1955 provisions on the protection of Germany's national cultural property with EU and international standards.

\section{Single European Market, export, and national cultural property laws}

EU law contains several provisions on cultural property. Most provisions, however, come under the heading of the movement of and trade in "cultural goods". Thus, the location of these provisions within the context of the SEM and the free movement of goods provide a strong indication of the economic orientation of the approach taken by EU law with respect to cultural property. In addition, the competence for cultural matters remains in the hands of the EU Member States, ${ }^{12}$ and as a consequence the EU has only a complementary competence in cultural matters in relation to the EU Member States. However, EU provisions have a great impact on the cultural property laws of the EU Member States, and with the creation of the SEM in 1993, customs controls were abolished in order to establish the free movement of goods without import and export restrictions between EU Member States. Articles 34 and 35 of the Treaty on the Functioning of the European Union (TFEU) set out the two general rules prohibiting quantitative restrictions on both imports and exports, as well as all measures having an equivalent effect. ${ }^{13}$ However, Article 36 TFEU - the only Article in the Treaty that specifically deals with the movement of cultural property - establishes a fundamental exception to the general principle of the free movement of goods and allows EU Member States to justify certain re-

10 Drucksache des Bundestages 18/7456 (3 February 2016), http://dipbt.bundestag.de/dip21/ btd/18/074/1807456.pdf [accessed: 21.09.2016]. Further documents, including those on the readings in parliament are available at: http://dipbt.bundestag.de/extrakt/ba/WP18/701/70170.html [accessed: 21.09.2016].

11 Convention for the Protection of Cultural Property in the Event of Armed Conflict, 14 May 1954, 249 UNTS 240 .

12 See Article 167 of the Treaty on the Functioning of the European Union (TFEU) ([consolidated version] OJ C 326, 26.10.2012, p. 47), which reads: "The Union shall contribute to the flowering of the cultures of the EU Member States, while respecting their national and regional diversity and at the same time bringing the common cultural heritage to the fore" (see ex Article 151 of the Treaty Establishing the European Community (TEC) [consolidated version], OJ C 325, 24.12.2002, p. 33).

13 See ex Article 28 and 29 TEC. 
strictions. In the context of cultural property this concerns "the protection of national treasures possessing artistic, historic or archaeological value". ${ }^{14}$

The basis for this exception rests on the necessity to reconcile the principle of the free movement of goods with the protection of national cultural property. Similarly to countries around the world, all EU Member States have enacted laws protecting national cultural property by prohibiting the export of certain types or categories of cultural property (regardless of their public or private ownership). Whereas Article 36 TFEU in the English and French versions refers to "national treasures" (French: trésors nationaux), the Italian and Spanish versions of Article 36 TFEU refer to "patrimonio nazionale" (Spanish: patrimonio nacional). The latter suggest a much broader understanding of "national heritage" or "national patrimony" than the term "national treasures", which indicates that the provisions might be limited to a few precious items. These terminological differences in the different versions of the EU Treaty imply that the legal concepts underlying the conceptualization of cultural property may vary as well. Similarly to UN treaty law, the EU Treaties do not grant supremacy to one language version over others; rather, the texts of all official languages are authentic. It is important to note here that while the UN has six official languages, the EU has twenty-four. ${ }^{15}$

The focus of this article is on the EU provisions regarding cultural property rather than a discussion of the effects of language discrepancies on the principles of EU treaty interpretation. That said, the German text of the EU Treaty might help to reconcile this disparate understanding of the concept, at least for the purpose of this article. The German text speaks of nationales Kulturgut, which simply refers to "national cultural goods" (or "national cultural property") and thus offers a mediating conceptualization. In addition, the 1970 UNESCO Convention - the major international convention on the protection of movable cultural property against illicit import, export and transfer of ownership, which currently has 131 States Parties - utilizes a similar conceptualization of "cultural property" within its statutory provisions. ${ }^{16}$ This brief analysis - with the "technical" assistance of the German text of the EU Treaty and, more importantly, with reference to the 1970 UNESCO Convention - demonstrates that the concept of "national treasures" in the English and French versions of Article 36 TFEU are too narrow. Several EU Member States with a very rich archaeological past, such as Italy and Greece, have a relatively high level

\footnotetext{
14 Article 36 TFEU reads: "The provisions of Articles 34 and 35 shall not preclude prohibitions or restrictions on imports, exports or goods in transit justified on grounds of public morality, public policy or public security; the protection of health and life of humans, animals or plants; the protection of national treasures possessing artistic, historic or archaeological value [italics mine]" (see ex Article 30 TEC).

15 There are six official languages of the UN: Arabic, Chinese, English, French, Russian and Spanish. All EU Member States' languages are official languages.

16 As of May 2016, 131 States Parties (by acceptance, ratification, or notification of succession). See current status of States Parties: www.unesco.org/eri/la/convention.asp?KO=13039\&language $=\mathrm{E}$ [accessed: 21.09.2016].
} 
of legal protection for national cultural property. Others, including many EU Member States in Northern Europe, offer less protection and provide a narrower definition of the types of artwork considered to be national cultural property. As a result, these EU Member States also restrict exportation to a lesser degree. In sum, due to the language discrepancies in various versions of Article 36 TFEU, it does not provide a uniform interpretation of the scope for the protection of national cultural property.

\section{The fairy tale of "internationalism" versus "nationalism"}

Bearing in mind that the competence for cultural matters lies with the EU Member States, it can be said that the definition of what "national cultural property" encompasses under Article 36 TFEU falls entirely within the competence of each EU Member State, reflecting its own conception of what should be protected as "national cultural property". The same applies to the 1970 UNESCO Convention, which states that "for the purposes of this Convention, the term, cultural property means property which, on religious or secular grounds, is specifically designated by each state as being of importance for archaeology, prehistory, history, literature, art or science" (Article 1) the loss of which would constitute "the impoverishment of the cultural heritage" (Article 2) of that state. Thus it is completely within the sovereignty of the state to designate what constitutes its national cultural property. As a result, the argument frequently presented by the art market that certain states protect too much of their cultural heritage is without any backing in EU and international law.

According to Merryman, ${ }^{17}$ "nationalism" refers to national constraints on the trade in cultural property, while the opposing concept of "internationalism" refers to a preference for free trade in cultural property and against national restrictions. However, "internationalism" is primarily nothing more than a substantiation of the free trade-approach, which exclusively fosters the interests of the so-called "art-market countries". What the concept of "internationalism" seems to have in mind is a general free trade in cultural property, unfettered by mutual cooperation among states. As such, mutual cooperation in cultural heritage would be, as a matter of fact, truly "international" and the rationale for cultural "internationalism" turns out to be not international, but rather simply commercial in nature. ${ }^{18}$

As a consequence, it is fundamental for states - EU Member States and the States Parties to the 1970 UNESCO Convention alike - to define, within their state sovereignty, national cultural property and to control both the import and export of their cultural property. This is usually accomplished through border and customs controls. In times of war, political unrest, or a failed state, the weakening or absence

17 J.H. Merryman, Two Ways of Thinking About Cultural Property, "American Journal of International Law" 1986, Vol. 80, pp. 831-853, 831.

18 J.A.R. Nafziger, The Present State of Research, in: J.A.R. Nafziger, T. Scovazzi (eds.), Le Patrimoine Culturel De L'humanité / The Cultural Heritage of Mankind, Nijhoff, Leiden - Boston 2008, p. 244. 
of these controls is frequently correlated with enormous increases in the illicit trafficking of cultural property, as is currently the case in Syria and Iraq, as well as in other regions. By deliberately relinquishing customs controls among EU Member States the creation of the SEM has a remarkably similar effect because it undermines the states' right to carry out export controls at national borders. In order to compensate for the abolition of national customs controls within the SEM (and more specifically the Schengen area), the EU adopted in 1992 Regulation 3911/92 on the export of cultural goods. ${ }^{19}$ This regulation is intended to ensure that the export of national cultural property outside the SEM is subject to uniform export controls at the EU's external borders.

\section{Single European Market and uniform EU export controls}

While the 1992 EU Regulation was subsequently codified by Regulation 116/2009, the conversion did not make major modifications to its contents. However, since a regulation is a legal act of the EU having general application and binding in its entirety, it is directly applicable in all EU Member States..$^{20}$ Therefore, it is immediately enforceable as law in all EU Member States without the need to be transposed into national law, whereas EU directives have to be transposed into national law, which serves to strengthen the uniformity of these provisions among EU Member States. On the basis of this EU export Regulation, the export of national cultural property outside the EU's customs territory is subject to the presentation of an EU export license. The competent authorities of the Member States (in most cases, the Ministry of Culture or subordinated offices) issue the EU export license. An export license is required if the cultural objects falls in one of the categories (type of object, age, and financial threshold) listed in Annex I to the Regulation. The Annex provides fifteen categories, including archaeological objects (over 100 years old, financial value: 0 Euro); paintings (over 50 years old; value of more than 150,000 Euro); photographs and films (over 50 years old, value of more than 15,000 Euro); and books (over 100 years old, value of more than 50,000 Euro). However, contemporary art, for example, is completely exempted from EU export licenses.

There is a notable difference in the quantity of export licenses issued by EU Member States under these provisions. Whereas each year Italy issues around 9,000 export licenses, and the United Kingdom and France issue around 8,000 and 3,000 licenses respectively, other EU Member States issue far fewer. For example, Germany issues approximately 1,200 licenses while Poland normally issues a mere 70 per year; in addition several EU Member States (e.g. Bulgaria or Greece)

19 Council Regulation (EEC) No. 3911/92 of 9 December 1992 on the export of cultural goods, OJ L 395, 31.12.1992, p. 1.

20 The legal basis for the enactment of regulations is Article 288 TFEU (ex Article 249 TEC). 


\section{RESEARCH ARTICLES}

Robert Peters

have been known to issue a single export license in a year. ${ }^{21}$ These widely different numbers of issued export licenses stem from a variety of factors, but a primary driver behind this variation lies in the different "quantities" of cultural objects and strength of national art markets (the United Kingdom being one of the largest in the EU). Moreover, it must be assumed that a certain number of cultural objects leave the SEM without an EU export license (and thus illegally) each year. As both an "island" within the SEM and an important art market, Switzerland creates an ideal loophole in this respect. This problem is further exacerbated by the availability of ample high-tech storage places for works of art within the country, and by the existence of several Swiss free ports.

In most cases, the EU export license is issued by the respective EU Member States and applications for a license can be refused. The basis for refusal is established in Article 2 of Regulation 116/2009: "The export license may be refused [...], where the cultural goods in question are covered by legislation protecting national treasures of artistic, historical or archaeological value in the Member State concerned." Thus, the Regulation enables the national authorities to check whether a certain object is or should be classified as "national cultural property" and, as a consequence, to prohibit the export. That said, only a small number of applications for an export license are refused. While Italy refuses around 80 per year, and Spain around 25 per year, the vast majority of EU Member States do not refuse more than one or two export licenses per year. ${ }^{22}$ In addition to the EU export license for the export outside the EU, most EU Member States have - in line with Article 36 TFEU - provisions that also require a national export license for the export to another EU Member State. These national export restrictions vary from Member State to Member State. Some are quite similar to the Regulation while others go beyond the Regulation by creating their own categories as well as age and financial thresholds, resulting in much stricter export controls. However, until the enactment of the new law Germany did not require a national export license within the SEM and thus did not make use of the possibilities contained in Article 36 TFEU. The 2016 reform introduces for the first time such a requirement by referring to the categories of Regulation 116/2009.

The application of Regulation 116/2009 is based on mutual trust and solidarity between EU Member States. It requires that each EU Member State control the export of not only its own national cultural property but also of the national cultural property of other EU Member States. This, however, creates several problems. Firstly, it is very difficult - if not impossible - for one Member State to verify with

${ }_{21}$ Report from the Commission to the European Parliament, the Council and the European Economic and Social Committee on the implantation of Council Regulation (EC) No. 116/2009 of 18 December 2008 on the export of cultural goods (1 January 2011 - 31 December 2013) of $1^{\text {st }}$ April 2015 (COM(2015) 144 final, Annex 1).

22 See ibidem. 
certainty - with the means provided and within reasonable time for the applicant of an EU export license - whether a certain painting, book or manuscript belongs to the national cultural property of another EU Member State. Secondly, the fifteen categories contained in the Annex of the Regulation are rather ambiguous. This has caused, in practice, difficulties in the proper and correct application and interpretation of the categories, in particular with regard to coins and single paleontological items that do not fit properly within the categories contained in the Annex of Regulation 116/2009. Thirdly, for understandable reasons of manageability in all Member States, the Regulation provides only a rough "filter" for national cultural property on the basis of age and financial thresholds. Most countries do not designate their national cultural property on the basis of monetary value. Thus it is not surprising that the thresholds have been criticized as being too high, particularly by new EU Member States. The art market, on the other hand, has repeatedly criticized the thresholds for being too low.

\section{Single European Market and the return of unlawfully removed cultural property between EU Member States}

With the creation of the SEM and the abolition of national customs controls, the EU adopted an additional legal instrument in 1993. Council Directive 93/7/EEC of 15 March 1993 on the return of cultural objects unlawfully removed from the territory of an EU Member State complements the EU Export Regulation, in order to reconcile the fundamental principle of the free movement of goods with the protection of national cultural property set out in Article 36 TFEU. Unlike the 1970 UNESCO Convention this Directive is not in itself an instrument against illicit trafficking in cultural property. Rather, it primarily compensates for the abolition of the national customs controls among EU Member States by discouraging illegal export within the SEM. It does so by creating the obligation to return unlawfully removed cultural property. Unlike EU Regulations, EU directives are not directly applicable. Therefore, directives require national implementation by each EU Member State before they take effect. Whereas Regulation 116/2009 requires a uniform EU export standard (so that all EU Member States issue the same EU export license), Directive 2014/60/EU sets minimal standards, thus allowing EU Member States to adopt higher (but not lower) standards in their national laws transposing the Directive. By employing the legal instrument of a directive rather than a regulation, the EU aims to establish harmonized minimal standards while still allowing EU Member States the flexibility to set higher ones if deemed appropriate by the respective national parliament.

The Council Directive 93/7/EEC provides for administrative cooperation in order to facilitate the return of cultural property. Therefore, Member States have several obligations under the Directive, such as appointing one or more central authorities to assist and cooperate with the other Member States. The obligation to return, however, does not apply to the Member State, but rather to the private in- 


\section{RESEARCH ARTICLES}

Robert Peters

dividual, namely the possessor (or, failing her/him, the holder) of the cultural object in question. Consequently, in the event negotiations and reaching an out-of-court settlement fail, the requesting EU Member State must initiate legal proceedings against the possessor before the competent court in another EU Member State. The requesting EU Member State must demonstrate that the cultural object belongs to its national cultural property and was unlawfully removed from its territory after 1 January 1993. If it fails to do so, the legislation does not provide a legal obligation for the object to be returned. Moreover, the scope of the 1993 Directive is restricted to cultural objects listed in the Annex to the Directive. This means that a certain cultural object, although protected by national law in a Member State, cannot be recovered under the Directive if it does not meet the age and financial thresholds contained in the Annex. Similarly to the EU Export Regulation, a "filter" limits the scope of the Directive. It is therefore unsurprising that since 1993 only a small number of cultural objects have been returned under the auspices of this Directive, and that an even smaller number of judicial claims for return were lodged in national courts.

\section{Directive 2014/60/EU: new provisions on the return of cultural property and due diligence}

Based on regular reports on the application of the Directive and following a process of evaluation with the EU Member States, the European Commission proposed the revision of Council Directive 93/7/EEC. On 15 May 2014, the European Parliament and the Council adopted a recast of the Directive in order to overcome several of its shortcomings. In comparison with its predecessor, Directive 2014/60/EU23 contains four substantial modifications. First of all, it extends the scope of the legislation by revoking the Annex. As a result of this change, all cultural objects classified or defined as national cultural property by EU Member States must be returned, and the Annex's restrictions based on age or financial thresholds are eliminated. This is consistent with Article 36 TFEU, insofar as it is entirely up to the Member States to designate their national cultural property. Secondly, the revised Directive extends the time limit for initiating return proceedings: instead of one year, EU Member States have now three years in order to substantiate their request for return. In practical terms, this means more time for investigation and more time to assert the claim against the possessor or, failing her/him, the holder of the cultural object in question. Thirdly, the administrative cooperation between the national authorities of the Member States must be conducted through the Internal Market Information System (IMI); this fosters the exchange of information and creates a record of information exchanges which are more traceable for all authorities involved.

23 Member States were given 18 months to transpose the new provisions of the Directive into national law (19 December 2015). 
Fourthly and more importantly, the new Directive shifts the burden of proof with regard to the receipt of compensation, in cases when the competent national court orders the return of the requested object. Article 10 of Directive 2014/60/EU establishes a new framework for establishing due diligence: it is now the possessor of a requested cultural object - not the requesting Member State - who has to provide evidence that $\mathrm{s} /$ he exercised due diligence at the time of acquisition in order to receive compensation from the requesting EU Member State. Thus, Article 10 of the 2014 Directive can be viewed as a binding EU standard of due diligence for cultural property exchange, not only with respect to compensation. Interestingly, Article 10 corresponds practically verbatim with the provisions on due diligence contained in Article 4, para. 4 and Article 6, para. 2 of the 1995 UNIDROIT Convention on Stolen or Illegally Exported Cultural Objects. ${ }^{24}$ This is remarkable, since only half of the EU Member States have ratified the UNIDROIT Convention, and it clearly shows the importance the European Parliament and the Council attributed to the question of due diligence. Moreover, it shows the intent to streamline EU law with existing international law.

Only the application of the new EU Directive over the course of the next few years will conclusively demonstrate the extent to which the modifications of the recast 1993 Directive will improve the mechanism for the return of unlawfully removed cultural objects among EU Member States. In practice, however, it will continue to be difficult for the requesting EU Member State to prove that a certain object was unlawfully removed from its territory after 1 January 1993 since the burden of proof remains with the requesting state.

\section{Excursus: sanctions on the import and export of and trade in cultural property from Iraq and Syria}

In addition to the provisions concerning the protection of Member States' national cultural patrimony on the basis of Regulation 116/2009 and Directive 2014/60/EU, an important exception to the free movement of goods is made for Iraqi and Syrian cultural property. Article 3 of Regulation (EC) No. 1210/2003 of 7 July 2003 prohibits the import, export or trade in all Iraqi cultural property. There are two exceptions to this prohibition. ${ }^{25}$ Firstly, if the possessor of the cultural object in question can prove that the object in question was exported from Iraq prior to 6 August 1990; and secondly if the object is officially being returned to Iraqi institutions in accordance with the objective of safe return as set out in para. 7 of UN Security Council Resolution 1483 (2003). Similarly, the EU has also adopted Regulation (EU) No. 1332/2013 of 13 December 2013 concerning restrictive measures in view of

2424 June 1995, 34 ILM 1322.

25 Council Regulation (EC) No. 1210/2003 of 7 July 2003 concerning certain specific restrictions on economic and financial relations with Iraq and repealing Regulation (EC) No. 2465/96, OJ L 169, 8.07.2003, p. 6. 
the situation in Syria. ${ }^{26}$ Similarly to EU Export Regulation 116/2009, both of these regulations are directly applicable. Thus, the import and export of and trade in Iraq and Syrian cultural objects are banned throughout the entire SEM.

\section{The four pillars of the 2016 reform of German cultural property law}

Although the respective EU Regulations - the export Regulation 116/2009 and both Regulations on Iraq and Syria - are directly applicable in all EU Member States, they do not provide legal provisions concerning the competence and jurisdiction of the respective national authorities (who can do what, and who informs whom). Since, however, EU Member States only have to transpose EU Directives (and not Regulations), specific provisions for the application of the Iraq and Syria Regulations were missing in Germany, especially with regard to proceedings for the return of seized objects from Iraq and Syria. This defect in applying the EU Regulations at the national level was only one of the problems outlined in the German federal government report of $2013^{27}$ that led to the 2016 reform of cultural property law in Germany.

The major problem outlined by the report was the deficiency in the 2007 law implementing the 1970 UNESCO Convention. The 2007 law was not uncontroversial during the legislative process: German legislators were faced with the twofold task of fulfilling the international obligations set out in the 1970 UNESCO Convention and at the same time avoiding unreasonable burdens and competitive disadvantages for the German art and antiquities market. The 2007 law on the return of cultural property was consequently a political compromise by all the parties involved, aimed at achieving an implementation that was "neither too lax and hence damaging to Germany's reputation nor too strict and thus no longer practicable". ${ }^{28}$ Being aware of the political compromise the Bundestag and Bundesrat therefore requested that, with the adoption of the 2007 law, the federal government submit an evaluation report on the impact of the law. This evaluation requirement, which was met by the 2013 report, was thus part of the political compromise forged in 2007.

The 2013 report came to the conclusion that, firstly, the excessive burden on the German art and antiques market, which was feared in 2007 , had failed to materialize. Secondly, the report noted that despite several requests for return submitted by foreign states, in not one single case had the 2007 law actually led to a return of cultural property. The reason was that the law's relatively high requirements for a return could not be met by any state seeking return. Thirdly, existing difficulties associated with the application of the law could not be remedied by jurisprudence.

26 Council Regulation (EU) No. 1332/2013 of 13 December 2013 amending Regulation (EU) No. 36/2012 concerning restrictive measures in view of the situation in Syria, OJ L 335, 14.12.2013, p. 3.

27 Report of the Federal Government on the protection of cultural property in Germany, op. cit.

28 See the explanatory memorandum to the Act on the Return of Cultural Property, Drucksache des Bundestages 16/1371 of 4 May 2006, general part, p. 12 [in German only]. 
Fourthly, the report found that the 2007 law had significantly strained Germany's bilateral and multilateral relations. In sum, it was quite a staggering outcome from the evaluation, but an honest approach to the problem. The report concluded with specific suggestions for amending Germany's cultural property laws, mainly with regard to four major aspects, which can be seen as the four pillars of the 2016 reform: (1) import and export provisions; (2) provisions for the return of cultural property; (3) due diligence provisions in dealing with cultural property; and (4) penal sanctions.

\section{Import and export provisions}

First of all, the 2016 law provides for harmonized import and export regulations. Whereas the import regulations of the 2007 law required the establishment of inventories of cultural property protected by foreign states, the new law relies on the simple equation that cultural property illegally exported from one state is considered as illegally imported into Germany. Thus, the new German law enforces all foreign export rules for cultural objects in line with the 1970 UNESCO Convention. With regard to cultural property in Germany, the new law requires an export license not only for the export from Germany outside the SEM - based on Regulation 116/2009 - but also - in line with Article 36 TFEU - for an export outside of Germany but inside the SEM. Whereas the vast majority of EU Member States have already adopted national export provisions like those Germany now has, only the Netherlands (as well as parts of Belgium) do not require such an export license within the SEM. In consequence, the new law does not differentiate between an export to Switzerland or France with regard to the requirement of an export license. In order not to overly unburden the German art and antiquities market, the financial thresholds for an export license within the SEM have been at least doubled with regard to the categories of cultural property under Regulation 116/2009.

\section{Provisions for the return of cultural property}

Secondly, the conditions for the return of illegally exported cultural property are streamlined with international standards. Whereas the 2007 law granted entitlement to return only for those cultural objects which had been entered in a public list of a foreign state and were accessible for inspection in Germany (for example online), the new law grants a right to return for all cultural objects that were illegally exported from another State Party to the 1970 UNESCO Convention after the date of both the requesting State's and Germany's ratification of the 1970 UNESCO Convention (which Germany ratified on 26 April 2007). With regard to EU Member States, the new law transposes the provisions for the return of cultural property as set out by Directive 2014/60/EU. 


\section{RESEARCH ARTICLES}

Robert Peters

\section{Due diligence provisions in dealing with cultural property}

Thirdly, and probably most importantly, the new law establishes the due diligence provisions not only for the professional art and antiquities market but also for everyone selling cultural property, e.g. online on an auction platform. These new due diligence provisions do not require the impossible but do require the seller to make sure that the object has not been stolen, illegally exported, or illegally excavated. Such provisions are also in line with modern standards of consumer protection: a buyer should be assured of his financial investment and not bear the risk of being confronted with a claim for return made by a foreign state. Moreover, the new law makes legal reference to the ICOM Red Lists of cultural objects at risk ${ }^{29}$ and thus incorporates the ICOM Red List into the due diligence requirements for the professional art and antiquities market in Germany.

\section{Penal sanctions}

Fourthly, the new law provides for stronger penal sanctions (up to five years of imprisonment) and administrative offences in case of violation of the import and export, and due diligence requirements. Although the new law will not solve all problems, it is a major step to combating the illicit trafficking in cultural property. Penal sanctions are part of such a robust system.

\section{What is lacking: EU import regulation for cultural property}

As discussed above, the EU Export Regulation No. 116/2009 and Directive 2014/60/EU on return are aimed at protecting the national cultural property of EU Member States. This legislation was necessary in order to allow Member States to exercise their right - granted by Article 36 TFEU - to protect their national cultural property. However, a key element in the protection of cultural property is still lacking. With the exception of the import restrictions on Iraqi and Syrian cultural objects, the EU does not provide for general import regulations in order to control the import of unlawfully removed cultural property from outside the EU. This creates a loophole, whereby unlawfully removed cultural property from outside the EU (even from the State Parties to the 1970 UNESCO Convention) can enter the SEM without any import controls. Once these objects are within EU borders, smugglers benefit from the free movement provisions of the SEM, particularly the absence of national customs controls among EU Member States. In other words, trafficking in cultural property is not suppressed, but rather encouraged by the current state of EU legislation. As a consequence of the SEM, Member States do not have the competence to adopt measures in this field. Since national measures cannot prevail within a single market, this problem is a matter for the EU to remedy.

29 Red Lists, International Council of Museums (ICOM), http://icom.museum/resources/red-lists-database/ [accessed: 21.09.2016]. 
With regard to the current import restrictions, the small number of cultural objects from Iraq and Syria that have been seized in the EU demonstrates that there are several obstacles in the practical application of both regulations. Most notably, these regulations can be circumvented if the importer of cultural property claims that the object originated from another state in that region (for example Jordan or the UAE). Accurate identification of the origin of cultural property is extremely difficult, costly, and time consuming. Therefore, the restrictive measures in the case of Iraq and Syria seem to have little effect in practice, due to the problem of proof of origin. Hence, a general EU import regulation is needed, also because most EU Member States cannot meet their legal obligation "to prohibit the import of stolen cultural property" as established in Article 7 of the 1970 UNESCO Convention. Currently, only three EU Member States have not ratified the 1970 UNESCO Convention: Ireland, Latvia and Malta. One solution to this problem would be the ratification of the 1970 UNESCO Convention by the EU as a whole. The EU did join, for example, the UNESCO 2005 Convention on Cultural Diversity in $2006 .{ }^{30}$ However, Article 29 of this more recent UNESCO 2005 Convention provides for accession by a "regional economic integration organization". Similar provisions are absent from the 1970 UNESCO Convention and the UNIDROIT 1995 Convention, both of which only allow States to join the Convention.

Since EU ratification of the 1970 UNESCO Convention is not permitted - unless the Convention is amended by a protocol - the only option is to adopt a new EU regulation on import restrictions. A recent proposal led by Germany calls for the adoption of an EU import regulation in order to combat trafficking in cultural property into the SEM. Such an instrument would also improve the implementation of the 1970 UNESCO Convention in the EU Member States already party to the Convention. Based on the proposal of Germany, an important first step was taken in the realization of an EU import regulation through the proposal's inclusion in the Work Plan for Culture (2015-2018), as adopted by the Council on 25 November 2014. ${ }^{31}$ The Commission will prepare a study, to be presented in 2017, on "Illicit trafficking of cultural objects, including EU import rules for cultural objects illegally exported from third countries"32. At UNESCO's general conference in November 2015, the French president François Hollande presented a report prepared by the Director of the Louvre, Jean-Luc Martinez, on strengthening France's efforts in fighting illicit trafficking in cultural property. Hollande stressed that the "huge wave of emo-

\footnotetext{
30 UNESCO Convention on the Protection and Promotion of the Diversity of Cultural Expressions, 20 October 2005, 2440 UNTS 311.

31 Work Plan for Culture (2015-2018) doc. 14491/14, Cultural Property issues D 3 c (p. 17 of the Work Plan for Culture), http://data.consilium.europa.eu/doc/document/ST-16094-2014-INIT/en/pdf [accessed: 21.09.2016].

32 Conclusions of the Council and of the Representatives of the Governments of the Member States, meeting within the Council on a Work Plan for Culture (2015-2018), p. 17, http://data.consilium.europa.eu/ doc/document/ST-16094-2014-INIT/en/pdf [accessed: 21.09.2016].
} 
tion created by the destruction in the Middle East" could trigger a global response against the illicit trade. ${ }^{33}$ In the same vein, the culture ministers of France, Germany and Italy addressed the importance of an EU import regulation in a joint statement to the EU Commission in early December $2015^{34}$ in order to underline the political willingness to move forward in improving the protection of cultural property and fight against illicit trafficking.

\section{Conclusions and future prospects}

Although the existing legal instruments, Regulation 116/2009, the codification of Regulation 3911/92, and Directive 2014/60/EU, as a recast of 93/7, were originally adopted in conjunction with the creation of the SEM in 1993 and thus derive from the necessity to reconcile the free movement of goods with the right of EU Member States to protect their national cultural property, it has been shown that further legislation at the EU level is needed. The destruction, looting and trafficking in cultural property, especially in Iraq and Syria, but also in other regions of political unrest, have demonstrated the need for the EU to move beyond protections that apply only to the national cultural property of EU Member States. Thus, the adoption of Regulation 1210/2003 on Iraqi cultural property and of Regulation 1332/2013 on Syrian cultural property, which ban the import, export and trade in these objects, as well as the provisions shifting the burden of proof in both instruments, indicate that the EU is moving in the right direction in combating the illicit trafficking of cultural property.

However, not only the crises in Syria and Iraq, but also the growing number of EU Member States ratifying the 1970 UNESCO Convention (Luxembourg in early 2015 and Austria in July 2015) illustrates the need for further action at the EU level. Without additional legislation, EU Member States are not in a position to meet their legal obligations under the Convention, since they ceded their competence on import controls to the EU through the creation of the SEM. Therefore, the EU must not only improve existing mechanisms - as it did through the recasting of the 1993 Directive in May 2014 - but also close loopholes, such as the lack of an import regulation on cultural property originating from outside the EU. The provision on due diligence in Article 10 of the new Directive provides hope that EU legislation can increase the standards in dealing with cultural property in the SEM, and maybe even beyond. It is, however, similarly important that states evaluate and, if needed, amend their national cultural property laws, as did Germany in 2016. In particular

\footnotetext{
${ }_{33}$ V. Noce, France builds grand alliance to protect cultural heritage, "The Art Newspaper", 4 January 2016, http://theartnewspaper.com/news/france-builds-grand-alliance-to-protect-cultural-heritage/ [accessed: 21.09.2016].

34 See the press release by the German Federal Government Commissioner for Culture and the Media, Illegaler Handel mit Kulturgut - Deutschland, Frankreich und Italien schreiben an die EU, https://www.bundesregierung.de/Content/DE/Pressemitteilungen/BPA/2015/12/2015-12-08-bkm-illegaler-handel.htmI?nn=811064 [accessed: 21.09.2016].
} 
the 1970 UNESCO Convention needs not only ratification but also implementation into national law, something that many States Parties to the 1970 UNESCO Convention have not yet done.

The path to combating trafficking in cultural property should not be difficult. In fact, a simple equation is sufficient: illegally exported cultural property from one state should be considered as illegally imported into another state. This simple equation should be the basis for future legislation, be it at the national, EU or international level.

\section{References}

Conclusions of the Council and of the Representatives of the Governments of the Member States, meeting within the Council on a Work Plan for Culture (2015-2018), p. 17, http://data.consilium.europa.eu/doc/document/ST-16094-2014-INIT/en/pdf [accessed: 21.09.2016].

Convention for the Protection of Cultural Property in the Event of Armed Conflict, 14 May 1954, 249 UNTS 240.

Council Directive 93/7/EEC of 15 March 1993 on the return of cultural objects unlawfully removed from the territory of a Member State, OJ L 74, 27.03.1993, p. 74.

Council Regulation (EEC) No. 3911/92 of 9 December 1992 on the export of cultural goods, OJ L 395, 31.12.1992, p. 1.

Council Regulation (EC) No. 1210/2003 of 7 July 2003 concerning certain specific restrictions on economic and financial relations with Iraq and repealing Regulation (EC) No. 2465/96, OJ L 169, 8.07.2003, p. 6.

Council Regulation (EC) No. 116/2009 of 18 December 2008 on the export of cultural goods (codified version), OJ L 39, 10.02.2009, p. 1.

Council Regulation (EU) No. 1332/2013 of 13 December 2013 amending Regulation (EU) No. $36 / 2012$ concerning restrictive measures in view of the situation in Syria, OJ L $335,14.12 .2013$, p. 3 .

Directive 2014/60/EU of the European Parliament and of the Council of 15 May 2014 on the return of cultural objects unlawfully removed from the territory of a Member State and amending Regulation (EU) No. 1024/2012, OJ L 159, 28.05.2014, p. 1.

Drucksache des Bundestages 18/7456 (3 February 2016), http://dipbt.bundestag.de/ dip21/btd/18/074/1807456.pdf [accessed: 21.09.2016].

Explanatory memorandum to the Act on the Return of Cultural Property, Drucksache des Bundestages 16/1371 of 4 May 2006, general part, p. 12 [in German only].

Forbes A., Kaplan I., Germany's onerous new art export law, explained, "Artsy Editorial”, 12 July 2016, https://www.artsy.net/article/artsy-editorial-what-germany-s-strict-new-regulations-mean-for-the-international-art-market [accessed: 21.09.2016].

Gesetz zur Ausführung des UNESCO-Übereinkommens vom 14. November 1970 über Maßnahmen zum Verbot und zur Verhütung der rechtswidrigen Einfuhr, Ausfuhr und Übereignung von Kulturgut [Act of 18 May 2007 Implementing the UNESCO Convention of 14 November 1970 on the Means of Prohibiting and Preventing the Illicit Import, Export and Transfer of Ownership of Cultural Property] (Federal Law Gazette, Part I, p. 757). 
Gesetz zur Neuregelung des Kulturgutschutzrechts - KGSG [Act of 31 July 2016 Reforming the Law on the Protection of Cultural Property], Bundesgesetzblatt (BGBI.) 2016 I S. 1914, entered into force on 6 August 2016, http://www.gesetze-im-internet.de/kgsg/ index.html [accessed: 21.09.2016].

Gesetz zum Schutz Deutschen Kulturgutes gegen Abwanderung - KultgSchG [Act to Prevent the Exodus of German Cultural Property], in the version published on 8 July 1999 (Federal Law Gazette, Part I, p. 1754).

http://dipbt.bundestag.de/extrakt/ba/WP18/701/70170.html [accessed: 21.09.2016].

Illegaler Handel mit Kulturgut - Deutschland, Frankreich und Italien schreiben an die EU, https:// www.bundesregierung.de/Content/DE/Pressemitteilungen/BPA/2015/12/2015-1208-bkm-illegaler-handel.html?nn=811064 [accessed: 21.09.2016].

Member States were given 18 months to transpose the new provisions of the Directive into national law (19 December 2015).

Merryman J.H., Two Ways of Thinking About Cultural Property, "American Journal of International Law" 1986, Vol. 80.

Nafziger J.A.R., The Present State of Research, in: J.A.R. Nafziger, T. Scovazzi (eds.), Le Patrimoine Culturel De L'humanité / The Cultural Heritage of Mankind, Nijhoff, Leiden - Boston 2008.

Noce V., France builds grand alliance to protect cultural heritage, "The Art Newspaper", 4 January 2016, http://theartnewspaper.com/news/france-builds-grand-alliance-to-protect-cultural-heritage/ [accessed: 21.09.2016].

Red Lists, International Council of Museums (ICOM), http://icom.museum/resources/ red-lists-database/ [accessed: 21.09.2016].

Report from the Commission to the European Parliament, the Council and the European Economic and Social Committee on the implantation of Council Regulation (EC) No. 116/2009 of 18 December 2008 on the export of cultural goods (1 January 2011 31 December 2013) of $1^{\text {st }}$ April 2015 (COM(2015) 144 final, Annex 1).

Report of the Federal Government on the protection of cultural property in Germany, adopted and presented to parliament (Bundestag) and the federal council of the Länder (Bundesrat) in April 2013 (Drucksache des Bundestages 17/13378), https://www. bundesregierung.de/ContentArchiv/DE/Archiv17/Artikel/2013/04/2013-04-24-kulturgutschutz.html [accessed: 21.09.2016].

Treaty Establishing the European Community (consolidated version), OJ C 325, 24.12.2002, p. 33.

Treaty on the Functioning of the European Union (consolidated version), OJ C 326, 26.10.2012, p. 47.

UNESCO Convention on the Means of Prohibiting and Preventing the Illicit Import, Export and Transfer of Ownership of Cultural Property, 14 November 1970, 823 UNTS 231.

UNESCO Convention on the Protection and Promotion of the Diversity of Cultural Expressions, 20 October 2005, 2440 UNTS 311.

UNIDROIT Convention on Stolen or Illegally Exported Cultural Objects, 24 June 1995, 34 ILM 1322.

Work Plan for Culture (2015-2018) doc. 14491/14, Cultural Property issues D 3 c (p. 17 of the Work Plan for Culture), http://data.consilium.europa.eu/doc/document/ST16094-2014-INIT/en/pdf [accessed: 21.09.2016]. 